\title{
Education in Pathology: What is the Place of Pathology Education in the "Online" Education Model?
}

\author{
(D) Özben Yalçın' ${ }^{1}$, (D) Zeynep Betül Erdem², (1) Halide Nur Ürer ${ }^{3}$, (D) Kutsal Yörükoğlu 4 \\ 1 University of Health Sciences Turkey, Prof. Dr. Cemil Taşçığlu City Hospital, Clinic of Pathology, Istanbul, Turkey \\ 2 University of Health Sciences Turkey, Başakşehir Çam and Sakura City Hospital, Clinic of Pathology, Istanbul, Turkey \\ 3 University of Health Sciences Turkey, Yedikule Chest Diseases and Thoracic Surgery Training and Research Hospital, Clinic of Pathology, Istanbul, Turkey \\ ${ }^{4}$ Dokuz Eylül University Faculty of Medicine, Department of Pathology, Izmir, Turkey
}

\section{Abstract}

In Turkish, education is derived from the verb root "bending", which means to bend, apply, teach, train, develop, exercise, dominate, defeat, crush, break, and direct. Considering the continuous and forward-moving role of pathology in modern medical practice, the importance of the concept of education in pathology becomes clear. In this review article, we aimed to create awareness of the dynamic and absolute continuous aspect of education in pathology.

Keywords: Pathology practice, online education, distance education

\section{INTRODUCTION}

According to the philosopher Kant, "Man can only be human through education, or he is nothing more than what education brings about". When we examine the educational relationships between people, we find that the same goal is always pursued (including today's "online" presentations and seminars) from primitive writings of thousands of years ago, such as murals, nails, and hieroglyphs, a phenomenon known as "educational instinct" . Considering the continuous and forward-moving role of pathology in modern medical practice, the importance of the concept of education in pathology becomes clear.

In Turkish, education is derived from the verb root "bending", which means to bend, apply, teach, train, develop, exercise, dominate, defeat, crush, break, and direct $(1,2)$. Approaches regarding the different learning characteristics of adults first coincided in the late 1940s. Regarding the theoretical basis of the studies on adult learning, Malcolm Knowles puts forward a detailed adult learning theory in his book, Adult
Student, published in 1973. Knowles introduced the concept of "andragogy", drawing attention to the fact that adults need certain situations to learn. By combining the words "andra", which means adult human, and "agosos", which means guiding, he created a discipline that examines adult education method (3). In this context, since our target audience in pathology education is residents and technicians, we must act with this discipline.

One of the most important principles in education is to make the participant understand why it is important to learn the subject (4). Especially, it is seen that trainings where cause and effect relationship is shown through examples and that those described with direct examples are more successful.

Campella (5) emphasizes in his work, The Land of the Sun, that having a craft and a profession glorifies one's self. We should emphasize how the technician and assistant will be more effective and how the given information would facilitate their work.

Phone: +90 5514286498 E-mail: zberdem@gmail.com ORCID ID: orcid.org/0000-0002-0840-4689

Cite this article as: Yalçın Ö, Erdem ZB, Ürer HN, Yörükoğlu K. Education in Pathology: What is the Place of Pathology Education in the "Online" Education Model? Eur Arch Med Res 2021;37(2):56-8

๑Copyright 2021 by the University of Health Sciences Turkey, Prof. Dr. Cemil Taş̧̧ığlu City Hospital European Archives of Medical Research published by Galenos Publishing House. 
Everyone's experiences are valuable for learning and, therefore, there is a versatile communication shared by all. It should be associated with the experiences of the participants and considered that the mature person's accumulation of experience constitutes an important resource in learning (6). In trainings attended by people from all seniorities and where experiences are shared, we see that the subject is more easily understood and memorable.

As stated in polytechnic education, learning by doing rather than memorization and theory is essential in education (7). Adults should be active in the learning process and learn by doing and experiencing. This is especially important for the acquisition of skills and their permanence. Although the information about macroscopy is explained verbally in pathology, it is seen that the resident is more effective when she/he starts to look at his own sample under the microscope. Adults tend to be hasty in applying their learned knowledge and have a problem-centered approach toward learning. They should be assisted to overcome their established behaviors, beliefs, and concerns about learning (8). Especially in routinely used techniques, more senior technicians and experts are seen to be more conservative in abandoning their habits. As stated by Descartes, "All that we understand very clearly and distinctly is true". In order to see the basic elements of the problem and the relationships between them, the issue should be structured and prepared in detail.

In fact, at this point, we are faced with a completely different education model, apart from all these written and experienced educational concepts. Atatürk said that "Science is the most real guide for civilization, life, and success in the world; to search for a guide other than science is absurdity, ignorance, and heresy" (9). An "online" education model has emerged due to the changing social conditions (such as the Coronavirus Disease-2019 pandemic) and the need to continuously renew or update the information, depending on evolving technology.

Founded in 1938, the International Council for Open and Distance Education defined the distance education model as the delivery of education to distant students with the help of tools, such as satellite, video, sound, graphics, computer, and multimedia technology.

One of the advantages of distant education is its costeffectiveness. It is a great convenience that everyone can access education without paying fees for travel, accommodation, and participation. In addition, the fact that a person can be connected to education from anywhere (home, work, and road) eliminates time and geographic difficulties. Our attention has been drawn to the fact that the number of participants in pathology courses and presentations has increased significantly in "online" presentations. It is also a great convenience to reach the recorded course/presentation at any time and place. Being away from the psychological pressure also provides an advantage for the learning process. In this context, it is another remarkable concept that "online" courses offer and ask more questions than the internet environment and that all kinds of comments can be made.

In addition to these, "online" education has disadvantages, such as connection problems and preventable disruptions, including interruption of incoming sound and video due to poor internet access. Wherever there is human activity, there is communication and communication is the basis of social life. The origin of the concept of communication is the word "communis" in Latin. The concept of communication has nearly five thousand uses. Some of its uses are as follows: Exchange of thought, understandingexplaining, interaction, reducing uncertainty, transfer process, process of change, process of establishing connections, process of sharing, tool-method-techniques, stimulation of memory, responding, stimulating, influencing, and transition process (10). Failure to meet the needs of using expressive elements, such as human facial expressions and body movements, in "online" trainings, not being able to make affirmation-reinforcement movements, and lack of social activities (coffee, tea drinkingmeal conversations, and meeting new people) negatively affects education.

Although the Standardization Committee of Federation of Turkish Pathology Societies regularly organizes courses, a more structured course program has been implemented in the last four terms. In these courses, participants' profile was determined by a test. This test was done before and after the course and the contribution to the course was questioned. In the second period, it aimed to educate the trainers, but had the participation of a limited number of volunteers. According to a study, students keep in mind $10 \%$ of what they read, $26 \%$ of what they hear, $30 \%$ of what they see, $50 \%$ of what they see and hear, $70 \%$ of what they say, and $90 \%$ of what they say about what they do (11). Each participant was asked a question and it was ensured that they present their answer to other participants attending the course. After this presentation, the subject was discussed and all questions were answered. A total of 51 residents, 434 technicians, and 167 experts, totaling up to 652 people, was reached in 17 courses held in three terms. Recently, due to the pandemic, the course was held online. "We are rebuilding our pathology laboratory: '5N1K' in quality standards. You ask, let us explain!" titled course was held on two separate dates and 185 and 123 people attended these courses, respectively. Video 
recordings of these courses have been made available on the web page.

Results of the third course (12) and the feedback of the latest "online" test show that a single form of education is not enough in pathology education. Regardless of the education model, it emerges that students should come to education by working, effectively using audio and visual elements in education, and devoting sufficient time to questions and answers during and after the education.

\section{CONCLUSION}

As a result, education in pathology is a continuous process that is responsible for innovations. With the awareness of the dynamic and absolute continuous aspect of education, we should always aim further in education, in whatever form and condition it may be, especially in the field of pathology, which has many details.

\section{Ethics}

Peer-review: Internally peer-reviewed.

\section{Authorship Contributions}

Concept: Ö.Y., Z.B.E., H.N.Ü., K.Y., Design: Ö.Y., Z.B.E., H.N.Ü., K.Y., Data Collection or Processing: Ö.Y., Z.B.E., Analysis or Interpretation: Ö.Y., H.N.Ü., K.Y., Literature Search: Ö.Y., Z.B.E., Writing: Ö.Y., Z.B.E.
Conflict of Interest: No conflict of interest was declared by the authors.

Financial Disclosure: The authors declared that this study received no financial support.

\section{REFERENCES}

1. Banguoğlu T. Türkçenin Grameri. Türk Dil Kurumu Yayınları; 1990.p.292.

2. Eyüpoğlu IZ. Türk Dilinin Etimoloji Sözlüğü. İstanbul: Sosyal Yayınları; 1991.p.220

3. Hartree A, Malcolm Knowles. Theory of Andragogy: A Critique. International Journal of Lifelong Education 1984;3:203-10.

4. Ergün M. Eğitim Felsefesi. 6. Baskı. Pagem Akademi; 2018.

5. Campanelle T. Güneș Ülkesi. Borda-Siyah Klasik Yayınları; 2004.p.39-43.

6. Sönmez V. Eğitim Felsefesi. 15. Baskı. İstanbul. Anı yayıncılık; 2019.p.130-

7. Aytaç K. Politeknik Eğitim Reformları (Teori ve Uygulamalar). A. Ü. Dil ve Tarih-Coğrafya Fakültesi; 1979.p.26.

8. Başaran IE. Eğitim Bilimine Giriș. 2. Baskı. Siyasal Kitabevi; 2007.p.96101.

9. Sevim A. Atatürk'ün söylev ve demeçleri-Bugünkü dille. Atatürk Araștırma Merkezi; 2016.

10. Zıllıoğlu M. Illetișim Nedir? Cem Yayınevi; 2014.p.32.

11. http://www.rehberlikservisim.com/wp-content/uploads/2015/11/ Verimli-Calisma-Teknikleri-.pdf

12. Yörükoğlu K, Ürer HN, Durgut U. "Hedefe Yönelik Tedavide Patoloji Süreçlerinin Önemi” Kursu: Sonuçları ve Öneriler. J Curr Pathol 2019;2:93-104. 